\title{
Relevansi Pemikiran Paulo Freire dengan Kemampuan Berpikir Kritis Matematis Siswa Sekolah Menengah Pertama
}

\author{
Syarifuddin $^{1 *}$, Lala Anggraini ${ }^{2}$, Fa'iz Azmi Fauzia $^{3}$ \\ ${ }^{1}$ Universitas Pendidikan Indonesia, Bandung, Jawa Barat 40154, Indonesia \\ ${ }^{2,3}$ Universitas Muhammadiyah Surabaya, Surabaya, Jawa Timur 60113, Indonesia \\ Pengiriman: 07/Maret/2021; Diterima: 25/Maret/2021; Publikasi: 31/Maret/2021 \\ DOI: https://doi.org/10.31629/jg.v6i1.3117
}

\begin{abstract}
Abstrak
Penelitian ini dilakukan untuk melihat dan mendeskripsikan pemikiran Paulo Freire dan kemampuan berpikir kritis matematis siswa sekolah menengah pertama (SMP) serta untuk melihat ada tidaknya relevansi atau hubungan antara keduanya. Penelitian ini menggunakan metode penelitin kualitatif dengan desain kepustakaan. Data dalam penelitian ini terdiri dari data primer (utama) yang diperoleh dari buku, pemikiran dan karya yang ditulis Paulo Freire dan data sekunder sebagai data pendukung dari data primer yang diperoleh dari jurnal, buku dan laporan hasil penelitian yang relevan. Analisis data yang digunakan dalam penelitian ini adalah analisis deskriptif, dimana data diolah dan dianalisis sesuai dengan studi literatur yang sudah dikumpulkan dan kemudian dideskripsikan untuk memperoleh hasil dan kesimpulan. Hasil dari penelitian ini adalah adanya relevansi antara pemikiran Paulo Freire dan kemampuan berpikir kritis matematis siswa SMP diantaranya yaitu, (1) dalam pembelajaran matematika, siswa diberikan kebebasan untuk mengembangkan kemampuan berpikir kritis melalui metode inquiry dan dialog terbuka yang sesuai dengan konsep pendidikan humanis Paulo Freire, (2) standart isi pelajaran matematika sekolah dasar dan menengah yang menuntut adanya perkembangan berpikir kritis dalam diri siswa yang sejalan dengan buah pemikiran dari Paulo Freire, (3) memposisikan siswa sebagai partner belajar atau subjek di dalam proses pembelajaran.
\end{abstract}

Kata kunci: Paulo Freire; berpikir kritis matematis

\begin{abstract}
This research was conducted to see and describe Paulo Freire's thinking and mathematical critical thinking abilities of junior high school (SMP) students and to see whether there is any relevance or relationship between the two. This study uses a qualitative research method with a library design. The data in this study consisted of primary data (main) obtained from books, thoughts and works written by Paulo Freire and secondary data as supporting data from primary data obtained from journals, books and reports of previous research relevant to the research. The data analysis used in this research is descriptive analysis, where the data is processed and analyzed in accordance with the literature study that has been collected and then described to obtain results and conclusions. The result of this research is that there is a relevance between Paulo Freire's thinking and junior high school students' mathematical critical thinking skills, namely, (1) in learning mathematics, students are given the freedom to develop critical thinking skills through the inquiry method and open dialogue in accordance with Paulo Freire's humanist education concept, (2) standard content of elementary and middle school mathematics lessons that require the development of critical thinking in students which is in line with the ideas of Paulo Freire, (3) positions students as learning partners or subjects in the learning process.
\end{abstract}

Keywords: Paulo Freire; mathematical critical thinking

*Penulis Korespondensi 


\section{JURNAL GANTANG. Maret 2021; VI(1): 93 - 102 \\ p-ISSN. 2503-0671 \\ e-ISSN. 2548-5547}

\section{Pendahuluan}

Matematika merupakan disiplin ilmu yang sangat mengandalkan proses berpikir kritis sehingga sangat baik utuk diajarkan pada anak didik (Syahbana, 2012). Dalam dunia pendidikan, matematika memiliki peran yang sangat signifikan dalam kehidupan manusia karena menjadi wadah atau sarana untuk memperbaiki sikap dan perilaku melalui cara berpikir kritis. Supaya manusia dapat bertindak atau berbuat demikian, maka mereka harus berusaha memperoleh pengetahuan yang benar berkaitan dengan keberadaan segala sesuatu yang ada, caranya yaitu mereka harus melakukan proses berpikir untuk mengetahui apa, darimana, dan bagaimana tujuan dari keberadaan tersebut. Berdasarkan makna dan hakikat filsafat, maka sejatinya pendidikan memiliki peran untuk membangun filsafat hidup manusia, agar dapat dijadikan sebagai petunjuk dan pedoman dalam menjalani kehidupan, agar dapat berjalan dengan baik dan teratur (Abdillah, 2017). Untuk itu sekolah harusnya tidak hanya menciptakan proses pembelajaran yang menjadikan siswa sebagai objek dari penyampaian materi yang disampikan oleh guru, tanpa diberikan kebebsan untuk melakukan proses refleksi dan koreksi atau bahkan kritis terhadap apa yang disampaikan oleh guru (Maufur, 2009). Karena hal itu akan sangat berdampak pada sikap dan perilaku kritis siswa dalam melihat dan menafsirkan fenomena kesenjangan sosial yang terjadi dalam kehidupan sehari-hari. Sekolah mestinya menjadikan peserta didik sebagai subjek yang bebas sehingga dapat menemukan sendiri pengetahuannya serta dapat meningkatkan kesadaran kritisnya dalam kehidupan sehari-hari (Suardi, 2018).

Di tengah upaya reformasi pendidikan yang terus dilakukan, pendidikan di Indonesia justru dihadapkan pada persoalan-persoalan laten yang itu dapat menghambat dan merusak pendidikan itu sendiri. Setidaknya ada tiga persoalan pendidikan yang menghambat kemajuan pendidikan di Indonesia saat ini: merebaknya nilai-nilai korporasi dalam dunia pendidikan, merebaknya budaya pragmatis dan kukuhnya ideologi kompetisi (Habudin, 2016). Bukan tanpa alasan jika memandang ketiga hal tersebut sebagai penyakit, karena merebaknya nilai-nilai korporasi akan sangat berpengaruh pada tujuan dari pendidikan itu sendiri. Pendidikan yang sejatinya sebagai sarana untuk meningkatkan kesadaran kritis dan kepekaan sosial serta perubahan perilaku peserta didik, justru diarahkan pada tujuan yang orientasinya hanya pada keuntungan dan hanya menghasilkan lulusan yang siap jadi pekerja dan buruh pabrik atau perusahaan (Al-Fadhil, 2016). Sedangkan budaya pragmatis atau positivism melahirkan karakter yang berakibat pada lemahnya nalar kritis peserta didik dalam memandang suatu kenyataan dan hanya memandang masyarakat dalam satu dimensi saja. Sementara ideologi kompetisi hanya menjadikan pendidikan seperti pabrik yang menghasilkan seorang pemenang dan pecundang yang hanya menguntungkan mereka yang cerdas dan memiliki kemampun ekonomi dan sosial serta sama sekali tidak berpihak kepada kaum tertindas, miskin dan terpinggirkan (Waseso, 2017).

Pendidik Marxis Paulo Freire (1970) mencirikan pendekatan pendidikan saat ini dengan metafora perbankan. Pikiran siswa seperti rekening tabungan di mana guru menyetornya (H.D., 2010). Menurut Freire "Education thus becomes an act of depositing, in which the students are the depositories and the teacher is the depositor. Instead of communicating, the teacher issues communiques and makes deposits which the students patiently receive, memorize, and repeat. This is the banking concept of education, in which the scope of action allowed to the students extends only as far as receiving, filing, and storing the deposits" (Freire, 2005) Dalam konsep ini, guru menarasikan materi pelajaran kepada siswa yang diharapkan secara pasif menerima, menghafal, dan mengulangi isi narasinya. Ini adalah dasar dari model pendidikan perbankan.

Menurut Roberts (2000) konsep dalam pendidikan perbankan memelihara dan bahkan menstimulasi kontradiksi melalui sikap dan 
praktik berikut, yang mencerminkan masyarakat yang menindas secara keseluruhan yaitu (a) guru mengajar siswa diajar; (b) guru tahu segalanya dan siswa tidak tahu apa-apa; (c) guru berpikir dan siswa memikirkan; (d) guru berbicara da siswa mendengarkan; (e) disiplin guru dan siswanya disiplin; (f) guru memiih dan memaksakan pilihannya, siswa mematuhinya; (g) tindakan guru dan siswa memiliki ilusi bertindak melalui tindakan guru; (h) guru memilih konten program, dan siswa menyesuaikannya; (i) guru mengacaukan otoritas pengetahuan dengan profesionalnya sendiri. Hal ini bertolak belakang dengan pemikiran Paulo Freire yang mengemukakan bahwa manusia memiliki kapasitas untuk mengubah nasibnya, artinya betapapun rendahnya kapasitas intelektual yang dimiliki manusia, Freire meyakini bahwa manusia memiliki kapasitas untuk melihat dunia secara kritis melalui dialektikan dan interaksi dengan manusia lainnya (Nuryatno, 2011).

Selain itu, hal lain yang menghambat kemajuan dan perkembangan pendidikan di Indonesia adalah cara pandang guru atau pengajar yang masih konservatif, kecanduan metode konvensional, terjebak pada instrumen dan administrasi pembelajaran atau bahkan pengelolaan pendidikan yang tidak visioner, sehingga dapat menghambat kemampuan dan potensi peserta didik dalam mengembangkan kapasitas diri dan kemampuan berpikir kritis mereka dalam proses pembelajaran (Pratama, 2019). Paulo Freire menyatakan bahwa pendidikan itu merupakan serangkaian dari tindakan dan fikiran, artinya ketika siswa bertindak dan berpikir, maka siswa akan menyatakan hasil dari tindakan dan pikirannya dalam bentuk kalimat atau ungkapan. Proses belajar yang seperti itu membuat siswa terlibat langsung dalam permasalahan realitas dunia yang mereka alami (Darwis, 2016). Inilah yang kemudian disebut oleh Freire sebagai model pembelajaran hadap masalah (problem posing education), dimana siswa dianggap sebagai subjek belajar, subjek yang melakukan tindakan dan proses berpikir dan pada saat yang bersaman mereka mengemukakan hasil dari tindakan dan buah pikirannya (Rohinah, 2019). Begitupun dengan guru, sehingga yang terjadi adalah antara murid dan guru sama-sama belajar dan saling memanusiakan.

Matematika adalah salah satu mata pelajaran yang mempunyai manfaat yang begitu besar di dalam kehidupan manusia, sehingga matematika wajib diajarkan kepada siswa mulai sejak dini hingga ke tingkat perguruan tinggi. Sesuai dengan Peraturan Menteri Pendidikan dan Kebudayaan No 22 Tahun 2006 tentang standar isi pelajaran matematika sekolah dasar serta menengah, dipaparkan bahwa pelajaran matematika bisa membekali siswa dengan bermacam keahlian, salah satunya adalah kemampuan atau keahlian berpikir kritis. Pelajaran matematika mempunyai kaitan yang sangat erat dengan keterampilan berpikir kritis siswa, hal itu disebabkan pelajaran matematika dapat dengan mudah dimengerti dengan kemampuan atau keahlian berpikir kritis dan begitupun sebaliknya (Mahmuzah, 2015). Maka dari itu, kemampuan berpikir kritis matematis harus dimiliki oleh setiap siswa dalam rangka menyelesaikan berbagai masalah matemtika siswa, terutama siswa sekolah menengah pertama (SMP).

Menanamkan kemampuan atau keterampilan berpikir kritis matematis kepada siswa dirasa perlu dilakukan oleh setiap guru, karena hal itu akan memberikan kemudahan kepada siswa untuk menyelesaikan berbagai masalah atau soal matematika yang membutuhkan analisis, penalaran, interpretasi pemikiran dan evaluasi (Sulistiani \& Masrukan, 2016). Sementara itu berpikir kritis merupakan kemampuan dalam mengidentifikasi, mengenalisis, mengevaluasi dan memecahkan masalah. Lebih jauh dijelaskan bahwa seorang yang memiliki kemampuan berpikir kritis dapat memilih dan menyeleksi berbagai infomasi untuk kemudian diambil keputusan yang tepat dan dapat dipercaya, sehingga dapat berguna dalam berbagai aktivitas kehidupan sehari-hari (Haeruman et al., 2017). Sedangkan menurut 


\section{JURNAL GANTANG. Maret 2021; VI(1): 93 - 102 \\ p-ISSN. 2503-0671 \\ e-ISSN. 2548-5547}

(Hidayat et al., 2019) berpikir kritis adalah proses berpikir secara mendalam agar dapat menghsilkan pengetahuan yang relevan dan dapat dipertanggung jawabkan. Sejalan dengan pemikiran Paulo Freire tentang konsep pendidikan pembebasan yang menjadikan siswa sebagai subjek dalam kegiatan belajar mengajar, maka proses kemampuan berpikir kritis juga demikian, dimana siswa diberikan kebebasan penuh untuk mengeksplorasi pengetahuan yang dimilikinya dalam rangka mengidentifikasi, mengevaluasi dan memecahkan masalah serta juga dapat mengambil kesimpulan yang tepat dan dapat dipertanggung jawabkan. Adapun manfaat dari penelitian ini adalah untuk mengetahui dan menggambarkan relevansi antara pemikiran Paulo Freire dengan kemampuan berpikir kritis matematis siswa Sekolah Menengah Pertama (SMP), serta dapat dimanfaatkan sebagai perbandingan atau referensi untuk penelitian yang relevan.

\section{Metode Penelitian}

Penelitian ini menggunakan metode penelitian kualitatif dengan desain kepustakaan (library research). Dalam penelitian ini akan dikaji dan dideskripsikan pengetahuan, gagasan dan penemuan yang terdapat di dalam literatur sehingga dapat memberikan informasi yang berkaitan dengan relevansi antara pemikiran Paulo Freire dengan kemampuan berpikir kritis matematika siswa sekolah menengah pertama (SMP). Teknik pengumpulan data dilakukan dengan cara dokumentasi dan mengidentifikasi informasi terkait dari buku, jurnal, laporan hasil penelitian dan dokumen resmi yang relevan. Sumber data dalam penelitian ini terdiri dari 1). Sumber data primer (utama) yang diperoleh dari buku, pemikiran dan karya-karya yang ditulis oleh Paulo Freire, seperti Pendidikan Kaum Tertindas, Politik Pendidikan: Kebudayaan, Kekuasaan dan Pembebasan, Pedagogy of Freedom: Ethics, Democracy, and Civic Courage, Education for Critical Consciousness dan lain sebagainya, 2). Sumber data sekunder yang menjadi data pendukung dari data primer yang membahas tentang konsep pendidikan pembebasan Paulo
Freire dan proses berpikir matematis siswa Sekolah Menengah Pertama (SMP), seperti misalnya buku Mazhab Pendidikan Kritis, Strategi Pembelajaran Matematika Kontemporer dan selain itu juga diperoleh dari jurnal penelitian seperti Peningkatan Kemampuan Berpikir Kritis Matematis dan Kemandirian Belajar Siswa SMP melalui Pembelajaran Berbasis Masalah, Peningkatan Kemampuan Berpikir Kritis Matematis Siswa SMP Melalui Pendekatan Problem Posing dan lain sebagainya.

Teknik analisis data yang digunakan dalam penelitian ini adalah analisis deskriptif, dimana data dianalisis dari uraian masalah objek kajian dan kemudian dideskripsikan untuk mendapatkan hasil dan kesimpulan.

\section{Hasil dan Pembahasan Pemikiran Paulo Freire}

Menurut Freire (2013) dijelaskan bahwa terdapat tiga pemikiran utama yang bisa diambil dari pemikiran Paulo Freire, yaitu (a) hakikat tentang manusia, (b) kerangka kesadaran manusia, (c) pendidikan sebagai tindakan politik. Pertama, filsafat tentang manusia. Freire berpendapat bahwa tidak ada filsafat atau teori yang berkaitan dengan pendidikan dapat dipisahkan dari konsep tentang manusia. Freire mengkitik pandangan yang mengemukakan bahwa manusia ibarat bejana kosong. Mualim (2017) mengemukakan bahwa bagi Freire manusia memiliki kemampuan dan pengetahuan serta pendapat yang bernilai. Meskipun pengetahuan dan kapasitas manusia rendah, Freire yakin bahwa setiap manusia mampu melihat secara kritis realitas yang ada di dalam dunia mereka melalui dialog dengan manusia lainnya (Salami \& Widyanto, 2018).

Kedua, kerangka kesadaran manusia. Freire membagi kesadaran manusia ke dalam tiga tingkatan, yaitu kesadaran semi-inransitif (kesadaran magis), kesadaran naif dan kesadaran kritis (Zaini \& Agustina, 2016). Kesadaran semiintransitif (kesadaran magis) ini merupakan kesadaran fatalistik. Kesadaran ini cenderung menghubungkan situasi dan kondisi individu atau komunitas dengan suatu kekuatan superior yang 
berasal dari luar mereka. Sehingga mereka harus patuh karena mereka tidak memiliki kontrol terhadap kekuatan supranatural tersebut (Moenawar et al., 2019). Sementara kesadaran naif merupakan kesadaran dimana manusia ditingkat ini sudah mampu menjadi subjek dan berdialog dengan manusia lainnya, namun belum sampai pada tahap memahami realitas. Manusia pada tahap ini sudah mulai mengetahui masalahmasalah dalam hidup mereka tetapi mereka tidak bisa melihatnya dengan cermat dan tidak berusaha mencari lebih dalam penyebab dan solusi dari masalah yang mereka hadapi. Sehingga mereka hanya menerima penjelasan-penjelasan ganjil atau keterangan sederhana yang diterima dari orang lain (Topatimasang et al., 2015). Kesadaran terakhir adalah kesadaran kritis, manusia pada tingkat ini sudah mampu menjadi subjek dan mampu melihat dan memahami realitas dengan sesungguhnya serta dapat menangkap fenomena (Tabrani, 2014). Dengan kesadaran seperti ini manusia akan terhindar dari sikap pesimis, fatalistik dan apatis, karena manusia pada tahap kesadaran ini lebih menekankan dialog dan berinteraksi dengan orang lain.

Ketiga, pendidikan sebagai tindakan politik. Paulo Freire memberikan tawaran bahwa pendidikan sebagai kritik terhadap kekuasaan dan politik, karena ketiganya saling berkaitan satu sama lain. Paulo Freire menekankan bahwa seharusnya pendidikan itu dapat menciptakan dan menghasilkan kehidupan masyarakat umum, bukan hanya sekedar menyesuaikan diri dengan realitas sosial. Pada hakikatnya, pendidikan itu merupakan miniatur kehidupan, apapun yang diajarkan oleh guru seharusnya berkaitan dengan kehidupan siswa. Seharusnya guru menyadarkan siswa bahwa mereka merupakan bagian dari masyarakat yang nantinya dapat memberikan perubahan ke arah yang lebih baik (Robikhah, 2018)

Menurut Freire (2008) pendidikan
merupakan proses humanisasi atau
memanusiakan manusia kembali. Pandangan ini
sesungguhnya berangkat dari hasil analisa bahwa
sistem kehidupan sosial, ekonomi dan politik

membuat manusia mengalami dehumanisasi. Perjuangan melawan dehumanisasi merupakan hal yang harus dilakukan, karena meskipun dehumaniasi merupakan kenyataan sejarah namun hal itu bukan merupakan takdir manusia melainkan hasil dari ketidak adilan yang melahirkan penindas dan pada akhirnya membuat kaum tertindas menjadi kurang dari memanusiakan manusia. Sejalan dengan hal itu (Hanif, 2014) mengemukakan bahwa pendidikan merupakan alat untuk menghasilkan kesadaran kritis siswa sebagai salah satu upaya untuk mengemblikan kembali sifat memanusiakan manusia setelah terjdinya proses dehumanisasi. Untuk mencapai hal tersebut maka pendidikan harus peka dan responsif terhadap segala tindakan ketidak adilan sosial dan penindasan dengan salah satu caranya adalah menjadikan siswa sebagai subjek penting dalam kegiatan belajar mengajar di dalam kelas. Sehingga siswa dapat membangun kesadaran kritisnya dalam rangka mewujudkan kepekaan dan kepribadian dalam dirinya.

\section{Kemampuan Berpikir Kritis Matematis Siswa}

Pelajaran matematika dan kemampuan berpikir kritis memiliki hubungan yang sangat erat serta saling melengkapi satu sama lain. Hal itu dikarenakan matematika akan lebih mudah dipahami dan dimengerti dengan kemampuan atau keterampilan berpikir kritis begitupun sebaliknya, kemampuan berpikir kritis bisa dilatih dan diasah melalui pelajaran matematika. Dalam menghadapi berbagai persoalan dan permasalahan dalam kehidupan bermasyarakat, maka salah satu kemampuan yang harus harus memiliki oleh seseorang adalah kemampuan berpikir kritis (Nuryanti et al., 2018). Sedangkan menurut Danaryanti \& Lestari (2017) berpikir kritis diartikan sebagai sikap berpikir yang mendalam, sesuai relitas atau fakta dan tidak berdasarkan imajinasi maupun angan-angan serta mempertimbangkan segala sesuatu supaya dapat mengambil kesimpulan dan keputusan yang harus diyakini dan dapat dipertanggung jawabkan. Menurut Chukwuyenum dalam (Haeruman et al., 2017) dijelaskan bahwa berpikir kritis adalah cara atau strategi yang sangat efektif untuk 


\section{JURNAL GANTANG. Maret 2021; VI(1): 93 - 102 \\ p-ISSN. 2503-0671 \\ e-ISSN. 2548-5547}

mempermudah siswa dalam memahami konsepkonsep, kemampuan ini dapat mempermudah siswa dalam menganalisis, menafsirkan, mengevaluasi, dan menyajikan data secara berurutan dan logis.

Kemampuan berpikir kritis dalam pelajaran matematika lebih diarahkan pada keterampilan siswa dalam menganalisis, mengidentifikasi, menghubungkan, mengevaluasi dan memecahkan masalah matematika. Dengan kemampuan berpikir kritis matematis, siswa akan lebih mudah mengidentifikasi, memahami dan menemukan solusi terbaik dari masalah atau kasus matematika yang dihadapinya (Haeruman et al., 2017). Kemampuan berpikir kritis ini memiliki kaitan yang sangat erat dengan rasa ingin tahu siswa karena halite dapat mendorong dan membantu siswa dalam melakukan penemuan yang baru. Sementara proses siswa dalam mencari dan menemukan sesuatu yang baru biasanya dilakukan melalui proses penyelidikan dengan menggunakan metode inquiry (Sari \& Wutsqa, 2019). Pendekatan inquiry ini yang menempatkan siswa sebagai subjek dalam belajar serta memberikan siswa kesempatan untuk mengeksplorasi dan mengembangkan cara berpikir ilmiah dalam memecahkan masalah. Menurut Jumaisyaroh et al. (2014) kemampuan atau keterampilan berpikir kritis matematis memiliki kegunaan yang sangat signifikan dalam diri siswa, sebab dengan keterampilan tersebut siswa bisa berpikir rasional dan dapat memilih dan menentukan opsi pemecahan terbaik untuk kasus yang dihadapinya. Bukan hanya itu, menanamkan keterampilan berpikir kritis terhadap siswa merupakan suatu hal yang harus dilakukan agar siswa bisa memahami dan menyelesaikan setiap masalah yang dihadapinya.

Menurut Abdullah (2013) kemampuan berpikir kritis matematis merupakan kegiatan berpikir yang dilakukan dengan cara-cara seperti berikut, yaitu memahami masalah dan merumuskannya, mengumpulkan informasi yang dapat dipercaya, menganalisa informasi yang dibutuhkan dan yang tidak dibutuhkan, merumuskan dugaan atau hipotesis, menguji hipotesis dengan logis, menarik kesimpulan, evaluasi, pengambilan keputusan dan kesimpulan serta melakukan estimasi dan generalisasi. Berdasarkan beberapa pengertian tersebut di atas dapat diartikan bahwa berpikir kritis matematis merupakan proses berpikir yang dapat memecahkan masalah dalam matematika dan kehidupan dengan cara mengidentifikasi, mengumpulkan dan menganalisis informasi, merumuskan hipotesis atau dugaan sementara dalam rangka mengmbil putusan yang benar dan dapat dipertanggungjawabkan.

\section{Relevansi Pemikiran Paulo Freire dengan Kemampuan Berpikir Kritis Siswa}

Pembatasan kajian pemikiran Paulo Freire dan kemampuan berpikir kritis matematis siswa di Sekolah Menengah Pertama (SMP) terbatas pada kerangka konsep, tujuan, metode atau pendekatan, posisi guru, serta posisi siswa yang dijelaskan dan digambarkan dalam tabel dibawah ini:

Tabel 1.

Relevansi pemikiran Paulo Freire dengan kemampuan berpikir kritis

\begin{tabular}{|c|c|c|}
\hline Aspek & Pemikiran Paulo Preire & $\begin{array}{l}\text { Kemampuan Berpikir } \\
\text { Kritis Matematis }\end{array}$ \\
\hline Kerangka Konsep & Pendidikan Humanis & $\begin{array}{l}\text { Berpikir secara mendalam terkait } \\
\text { konsep-konsep matematika }\end{array}$ \\
\hline Tujuan & $\begin{array}{l}\text { Terjadi perubahan dalam diri } \\
\text { siswa, baik perubahan dalam } \\
\text { kualitas berpikir maupun } \\
\text { kualitas sosial sehingga mampu } \\
\text { membaca realitas sosial dengan } \\
\text { kritis }\end{array}$ & $\begin{array}{l}\text { Membelajarkan siswa agar } \\
\text { memahami hakikat matematika, } \\
\text { agar mampu berpikir kritis } \\
\text { sehingga siswa lebih aktif dalam } \\
\text { kegiatan belajar mengajar } \\
\text { matematika }\end{array}$ \\
\hline Metode & $\begin{array}{l}\text { Kegiatan belajar mengajar lebih } \\
\text { ditekankan pada pendekatan } \\
\text { dialogis, dimana guru dan siswa } \\
\text { sama-sama subjek dalam } \\
\text { pembelajaran }\end{array}$ & $\begin{array}{l}\text { Metode inquiry yang menekankan } \\
\text { siswa untuk berpikir kritis dan } \\
\text { berpikir ilmiah }\end{array}$ \\
\hline Posisi Guru & $\begin{array}{l}\text { Guru sebagai fasilitator, } \\
\text { mediator dan motivator dalam } \\
\text { pembelajaran }\end{array}$ & $\begin{array}{l}\text { Pembimbing dan fasilitator dalam } \\
\text { pembelajaran }\end{array}$ \\
\hline Posisi Siswa & $\begin{array}{l}\text { Siswa sebagai pusat } \\
\text { pembelajaran }\end{array}$ & $\begin{array}{l}\text { Siswa merupakan subjek dalam } \\
\text { proses pembelajaran di dalam } \\
\text { kelas }\end{array}$ \\
\hline
\end{tabular}

Dari tabel 1 di atas, maka diperoleh penjelasan sebagai berikut:

Pemikiran Paulo Freire mengenai pendidikan humanisme merupakan pendidikan yang memanusiakan manusia dan menempatkan manusia seabagai pusat perubahan. Menurut Shor \& Freire (1987) terjadinya perubahan dalam proses pembelajaran dapat dilihat dari proses menemukan ulang (reinventing), menciptakan 
ulang (recreating) dan menuliskan ulang (rewriting) pengetahuan siswa. Hal itu berbanding terbalik dengan proses pembelajaran yang terjadi di dalam sistem pendidikan kita selama ini, yang hanya menjadikan siswa sebagai objek penerima materi dari penyampaian guru. Sistem pembelajaran seperti ini menurut Freire (2000) merupakan sistem pendidikan gaya bank, dimana proses pembelajaran hanya didominasi oleh guru dan siswa dianggap sebagai objek. Proses pembelajaran yang terjadi bukanlah proses dialog dan komunikasi antara guru dan siswa namun guru lebih banyak berbicara dan menenrangkan sedangkan siswa hanya mendengarkan dan menerima apa yang disampaikan oleh guru. Begitulah sistem pendidikan gaya bank, dimana siswa hanya diposisikan sebagai penerima, pencatat dan penyimpan semua materi yang disampaikan oleh guru. Sementara keberhasilan pendidikan ditekankan pada kemampuan siswa dalam memahami, menganalisis, mengumpulkan informasi, dan menarik kesimpulan dalam setiap masalah yang dihadapi. Hal tersebut sesuai dengan konsep pendidikan yang menekankan pada proses berpikir kritis siswa. Sejalan dengan hal itu, Paulo Freire menawarkan konsep pendidikan yang dialektis, dimana siswa dipaksa untuk saling berdialog dan belajar bersama dengan teman yang lainnya maupun antara siswa dengan guru, sehingga hal itu dapat membuat siswa mampu memahami realitas sosial dan saling menghargai satu sama lain.

Paulo Freire berusaha melakukan perubahan terhadap sistem pendidikan yang konvensional dan tradisional, karena sistem pendidikan yang seperti itu hanya menjadikan siswa sebagai objek dalam proses pembelajaran atau sistem pendidikan gaya bank. Pembelajaran matematika di sekolah menengah pertama (SMP) harusnya dilakukan dengan cara meberikan siswa kebebasan dalam mengeksplorasi pengetahuannya sendiri dengan metode inquiry dan proses berpikir kritis. Bukan malah menyajikan matematika sebagai sebuah konsep yang rumit dan seolah jauh dan terpisah dari realitas kehidupan sehari-hari siswa. Sejalan dengan pemikiran Paulo Freire tentang pendidikan pembebasan, guru harusnya menjadikan siswa sebagai subjek yang aktif dan dapat memfasilitsi siswa untuk mengaitkan konsep matematika dengan kehidupan nyata melalui kemampuan kritis yang dimilikinya. Sehingga yang terjadi adalah kebebasan intelektual di dalam proses kegiatan belajar mengajar matematika siswa di sekolah. Siswa dituntut untuk berpikir kritis dalam proses pembelajaran matematika di sekolah, hal itu dikarenakan salah satu tujuan pencapaian dari pelajaran matematika adalah kemampuan berpikir kritis itu sendiri, sehingga dengan demikian siswa dapat mencapai tujuan pelajaran matematika tersebut. Selain itu tujuan pembentukan kemampuan berpikir kritis dalam diri siswa adalah agar pembelajaran matematika berpusat pada persoalan mengapa dan bagaimana siswa mengetahui, sehingga yang terjadi adalah siswa lebih aktif dalam proses pembelajaran dan membentuk pengetahuannya sendiri.

\section{Kesimpulan}

Adapun kesimpulan dalam penelitian ini, sebagi berikut:

1. Proses kegiatan belajar mengajar matematika di SMP diarahkan pada pengalaman langsung siswa, dengan cara memberikan kebebasan kepada siswa melalui kemampuan kritis yang dimilikinya.

2. Konsep pendidikan menurut Paulo Freire menyatakan tentang:

a. Konsep pendidikan humanis, merupakan konsep pendidikan yang dapat mengangkat harkat dan martabat manusia

b. Konsep pendidikan pembebasan, yaitu memberi kebebasan kepada siswa untuk mengeksplorasi kemampuannya dalam mengaitkan pembelajaran dengan realitas sosial

c. Konsep pendidikan dialektis, yaitu konsep pembelajaran berlangsung 


\section{JURNAL GANTANG. Maret 2021; VI(1): 93 - 102

dua arah, dimana guru mengedepankan dialog dan belajar bersama dalam proses pembelajaran.

3. Sesuai dengan tujuan pendidikan Paulo Freire, maka siswa diharapkan mampu melakukan perubahan dalam dirinya, baik itu perubahan yang berhubungan dengan kemampuan berpikir maupun perubahan yang berhubungan dengan kemampuan berinteraksi sosial siswa di dalam masyarakat.

4. Relevansi pemikiran Paulo Freire dengan kemampuan berpikir matematis siswa:

a. Konsep pendidikan humanis Paulo Freire yang menempatkan siswa sebagai manusia yang utuh dan memiliki potensi serta kapasitasnya sendiri. Dalam pembelajaran matematika, siswa diberikan kebebasan untuk mengembangkan kemampuan berpikir kritis melalui metode inquiry dan dialog terbuka.

b. Tujuan dari pemikiran Paulo Freire adalah mengarahkan siswa untuk berpikir kritis terhadap relitas, hal ini sejalan dengan standart isi pelajaran matematika sekolah dasar dan menengah yang menuntut adanya perkembangan berpikir kritis dalam diri siswa.

c. Paulo Freire dengan konsep pendidikan yang digagasnya, memposisikan siswa sebagai partner belajar atau subjek di dalam proses pembelajaran, sedangkang guru bertindak sebagai fasilitator atau mediator siswa dalam belajar. Hal itu sejalan dengan pembelajaran matematika di sekolah menengh pertama yang memposisikan siswa atau peserta didik sebagai subjek dan guru sebagai fasilitator.

Hasil penelitian ini bisa dijadikan rekomendasi dan referensi bagi para pegiat dan peneliti pendidikan agar mengajarkan matematika di sekolah menengah pertama dengan cara dialogis dan siswa diberikan kesempatan untuk mengalami secara langsung proses pembelajaran melalui inquiry learning, dengan demikian terciptalah suasana belajar yang bebas dan dapat mengembangkan kemampuan kritis serta terwujudnya pendidikan yang humanis atau pendidikan yang dapat memanusiakan manusia.

\section{Referensi}

Abdillah, R. (2017). Analisis teori dehumanisasi pendidikan Paulo Freire. Jurnal Aqidah Dan Filsafat Islam, 2(1), 1-21.

Abdullah, I. H. (2013). Berpikir kritis matematik. Delta-Pi: Jurnal Matematika Dan Pendidikan Matematika, 2(1), 66-75. https://doi.org/10.18860/jt.v0i0.1442

Al-Fadhil, M. (2016). Mazhab pendidikan kritis; Proses humanisasi pendidikan. MUDARRISUNA (Media Kajian Pendidikan Agama Islam), 6(1), 33-52.

Danaryanti, A., \& Lestari, A. T. (2017). Analisis kemampuan berpikir kritis dalam matematika mengacu pada watson-glaser critical thinking appraisal pada siswa kelas VIII SMP Negeri di Banjarmasin Tengah tahun pelajaran 2016/2017. EDU-MAT: Jurnal Pendidikan Matematika, 5(2), 116126. https://doi.org/10.20527/edumat.v5i2.4631

Darwis, M. (2016). Paradigma baru pendidikan dalam perspektif pemikiran Paulo Freire. FITRA, 2(2), 62-68.

Freire, P. (2000). Pedagogy of freedom: Ethics, democracy, and civic courage. Rowman \& Littlefield.

Freire, P. (2005). Pedagogy of the oppressed. Bloomsbury.

Freire, P. (2008). Pendidikan kaum tertindas. LP3ES.

Freire, P. (2013). Education for critical consciousness. Bloomsbury.

H.D., A. (2010). Language minority students in american schools: An education in english. Lawrence Erlbaum Associates.

Habudin, I. (2016). Konstruksi pendidikan yang memanusiakan manusia: Transformasi pemikiran paulo freire dalam konteks pendidikan inklusif. Jurnal Difabel, 3(3), 119.

Haeruman, L. D., Rahayu, W., \& Ambarwati, L. (2017). Pengaruh model discovery learning 
terhadap peningkatan kemampuan berpikir kritis matematis dan self-confidence ditinjau dari kemampuan awal matematis siswa SMA di Bogor Timur. Jurnal Penelitian Dan Pembelajaran Matematika, 10(2), 157168.

https://doi.org/10.30870/jppm.v10i2.2040

Hanif, M. (2014). Desain pembelajaran untuk transformasi sosial (studi perbandingan pemikiran paulo freire dan ivan illich tentang pendidikan pembebasan). KOMUNIKA: Jurnal Dakwah Dan Komunikasi, $\quad 8(2), \quad$ 113-128. https://doi.org/10.24090/komunika.v8i2.75 2

Hidayat, F., Akbar, P., \& Bernard, M. (2019). Analisis kemampuan berfikir kritis matematik serta kemandiriaan belajar siswa smp terhadap materi spldv. Journal On Education, 01(02), 515-523.

Jumaisyaroh, T., Napitupulu, E. E., \& Hasratuddin. (2014). Peningkatan kemampuan berpikir kritis matematis dan kemandirian belajar siswa smp melalui pembelajaran berbasis masalah. Kreano: Jurnal Matematika Kreatif-Inovatif, 5(2), 157-169.

https://doi.org/10.15294/kreano.v5i2.3325

Mahmuzah, R. (2015). Peningkatan kemampuan berpikir kritis matematis siswa smp melalui pendekatan problem posing. Jurnal Peluang, 4(1), 64-72.

Maufur, H. F. (2009). Sejuta jurus mengajar mengasyikkan. PT Sindur Press.

Moenawar, M. G., Priatna, W. B., \& Santoso, H. (2019). Consciousness raising dan partisipasi politik suku baduy di era digital (tinjauan awal). Jurnal Komunikasi Pembangunan, 17(1), 69-80. https://doi.org/10.29244/jurnalkmp.17.1.6980

Mualim, K. (2017). Gagasan pemikiran humanistik dalam pendidikan (perbandingan pemikiran naquib al-attas dengan Paulo Freire). Al-ASASIYYA: Journal Of Basic Education, 01(02), 1-18.

Nuryanti, L., Zubaidah, S., \& Diantoro, M. (2018). Analisis kemampuan berpikir kritis siswa SMP. Jurnal Pendidikan: Teori, Penelitian, dan Pengembangan, 3(2), 155158.

http://journal.um.ac.id/index.php/jptpp/artic le/view/10490
Nuryatno, M. A. (2011). Mazhab Pendidikan Kritis. Resist Book.

Pratama, A. I. (2019). Inovatif dan konservatif dalam menghadapi era 4.0. tantangan guru menyikapi generasi digital-milineal. Seminar Nasional 2019 Islamisasi Ilmu Pengetahuan Di Era Revolusi Industri 4.0 (Makna Dan Tantangannya) Sekolah Pascasarjana Universitas Ibn Khaldun (UIKA), Vol.1(No. 1), 23-33.

Roberts, P. (2000). Education, literacy, and humanization: exploring the work of Paulo Freire. Bergin \& Garvey.

Robikhah, A. S. (2018). Paradigma pendidikan pembebasan paulo freire dalam konteks pendidikan agama islam. IQ (Ilmu AlQur'an): Jurnal Pendidikan Islam, 1(01), 1-16. https://doi.org/10.37542/iq.v1i01.3

Rohinah. (2019). Re-konsientisasi dalam dunia pendidikan (membangun kesadaran kritis melalui pemikiran Paulo Freire). Jurnal Tarbiyah: Jurnal Ilmiah Kependidikan, $8(1), \quad 1-12 . \quad$ http://jurnal.uinantasari.ac.id/index.php/jtjik/article/view/2 355

Salami, N., \& Widyanto, A. (2018). Etika interaksi edukatif antara pendidik dan peserta didik menurut perspektif al-zarnuji dan Paulo Freire. DAYAH: Journal of Islamic Education, 1(2), 164-181. https://doi.org/10.22373/jie.v1i2.2945

Sari, A. A. I., \& Wutsqa, D. U. (2019). Pengembangan perangkat pembelajaran matematika menggunakan pendekatan inquiry berorientasi kemampuan berpikir kritis. Pythagoras: Jurnal Pendidikan Matematika, 14(1), 56-70. https://doi.org/10.21831/pg.v14i1.27303

Shor, I., \& Freire, P. (1987). What is the "dialogical method" of teaching?. Journal Of Education, 169(3), 11-31.

Suardi, M. (2018). Belajar dan Pembelajaran. Deepublish.

Sulistiani, E., \& Masrukan. (2016). Pentingnya berpikir kritis dalam pembelajaran matematika untuk menghadapi tantangan MEA. Seminar Nasional Matematika X Universitas Negeri Semarang, 605-612.

Syahbana, A. (2012). Peningkatan kemampuan berpikir kritis matematis siswa melalui pendekatan contextual teaching and learning. Edumatica, 02(01), 45-57. https://doi.org/10.30822/asimtot.v2i2.769 
JURNAL GANTANG. Maret 2021; VI(1): 93 - 102

p-ISSN. 2503-0671

e-ISSN. 2548-5547

Tabrani, Z. A. (2014). Isu-isu kritis dalam pendidikan islam perspektif pedagogik kritis. Jurnal Ilmiah Islam Futura, 13(2), 250-270.

Topatimasang, R., Rahardjo, T., \& Fakih, M. (2015). Pendidikan popular: Membangun kesadaran kritis. INSISTPress.

Zaini, M., \& Agustina, W. (2016). Kajian kritis perilaku humanitas pendidik terhadap peserta didik dalam proses pendidikan di kota Malang. JINoP (Jurnal Inovasi Pembelajaran), 2(2), 373-388. https://doi.org/10.22219/jinop.v2i2.3490 